\title{
Prosecuting Public Officials Under the Hobbs Act: Inducement as an Element of Extortion Under Color of Official Right
}

The Hobbs Act has become a major federal weapon against corruption in state and local government. ${ }^{1}$ A wide variety of state and local officials-from a city electrical inspector to a governor-have been convicted of extortion under the Act. ${ }^{2}$ These offcials have been prosecuted for taking many different kinds of property, ranging from cash payments and campaign contributions to golf vacations and entertainment. ${ }^{3}$

By its terms the Act prohibits extortion affecting interstate commerce, with extortion defined as "the obtaining of property from another, with his consent, induced by wrongful use of actual or threatened force, violence, or fear, or under color of official right." 4 To reach state and local officials, federal prosecutors focus

${ }^{1}$ Hobbs Act, ch. 645, § 1951, 62 Stat. 793 (1946) (codified as amended at 18 U.S.C. $\S 1951$ (1982)). See infra notes 4, 8-13 and accompanying text. For a description of how the Act has been used to fight state and local corruption, see Ruff, Federal Prosecution of Local Corruption: A Case Study in the Making of Law Enforcement Policy, 65 GEo. L.J. 1171, 1172 (1977). Ruff notes that from 1970 to 1976 federal prosecutions of state and local officials increased more than $500 \%$, and that "the principal vehicle for this rapidly expanding federal effort is the Hobbs Act." Id. Between 1970 and 1981 there were 520 federal indictments of allegedly corrupt state officials and 1,757 federal indictments of local officials. See U.S. Dep't of Justice, Report to Congress on the Activities and Operations of the PubLIC INTEGRITY SECTION FOR 1981, at 20 (1982). Over the same period, 369 state officials and 1,290 local officials were convicted for corruption under federal law. Id.

${ }^{2}$ See United States v. Price, 617 F.2d 455 (7th Cir. 1979) (city electrical inspector); United States v. Hall, 536 F.2d 313 (10th Cir.) (governor), cert. denied, 429 U.S. 919 (1976).

${ }^{3}$ See United States v. Campo, 744 F.2d 944, 945 (2d Cir. 1984) (\$250 cash payment); United States v. Trotta, 525 F.2d 1096, 1097 (2d Cir. 1975) ( $\$ 3000$ campaign contribution), cert. denied, 425 U.S. 971 (1976); United States v. O'Grady, 742 F.2d 682, 697 n.1 (2d Cir. 1984) (en banc) (golf vacations and entertainment).

418 U.S.C. $\S 1951(b)(2)$ (1982). The Hobbs Act provides, in relevant part:

(a) Whoever in any way or degree obstructs, delays, or affects commerce or the movement of any article or commodity in commerce, by robbery or extortion or attempts or conspires so to do, or commits or threatens physical violence to any person or property in furtherance of a plan or purpose to do anything in violation of this section shall be fined not more than $\$ 10,000$ or imprisoned not more than twenty years, or both.

(b) As used in this section-

(1) The term "robbery" means the unlawful taking or obtaining of personal property from the person or in the presence of another, against his will, by means of actual or threatened force, or violence, or fear of injury, immediate or future, to 
on the last clause of this definition; payments received are characterized as property obtained "under color of official right." $\mathrm{Al}$ though federal courts agree that the Hobbs Act may be used to prosecute state and local officials, they do not agree about what act must be proved for conviction. The majority of the federal courts of appeals that have addressed the issue hold that officials commit the requisite act merely by receiving payments not due them under the law. ${ }^{5}$ Under this view, the public official need not commit any act inducing the payment; instead, the official's status and authority are said to exert a coercive force on the party making the payment. The Second Circuit, in contrast, requires the prosecution to show that the defendant actually induced the payment. Its test requires that the official must have initiated the transaction and must at least have subtly encouraged the payments. ${ }^{6}$

This controversy carries significant implications for federal prosecutions of state and local officials. If no act of inducement is required, the range of conduct within the proscription against extortion will be very broad. Consequently, public officials who continue the traditional practice of receiving inconsequential gratuities will risk stiff prison terms and fines. ${ }^{7}$ If courts do require an act of inducement, however, prosecutors must shoulder an additional burden of proof confounded by the secrecy of the proscribed transactions and the self-protective refusal of witnesses to testify.

This comment argues that public officials should be convicted

his person or property, or property in his custody or possession, or the person or property of a relative or member of his family or of anyone in his company at the time of the taking or obtaining.

(2) The term "extortion" means the obtaining of property from another, with his consent, induced by wrongful use of actual or threatened force, violence, or fear, or under color of official right.

(3) The term "commerce" means commerce within the District of Columbia, or any Territory or Possession of the United States; all commerce between any point in a State, Territory, Possession, or the District of Columbia and any point outside thereof; all commerce between points within the same State through any place outside such State; and all other commerce over which the United States has jurisdiction.

18 U.S.C. \& 1951(a)-(b) (1982).

- See infra notes 36-38 and accompanying text. The word "payments" is used in this comment to describe any property that may be at issue under the Act, including both cash payments and in-kind benefits. See 18 U.S.C. $\$ 1951(b)(2)(1982)$ (offense involves "the obtaining of property from another").

- See United States v. O'Grady, 742 F.2d 682, 691-92 (2d Cir. 1984) (en banc), discussed infra notes 47-63 and accompanying text; see also United States v. Paschall, 772 F.2d 68 (4th Cir. 1985), discussed infra note 49.

7 The Hobbs Act provides penalties of up to twenty years in prison and a $\$ 10,000$ fine. See 18 U.S.C. § 1951(a) (1982). 
of extortion under color of official right only when they actually induce payments to which they have no legal right. While embracing the Second Circuit's major conclusion, the comment departs from it both in the justifications for the inducement requirement and in the standard for determining what constitutes inducement. Part I describes current judicial interpretations of the actus reus of the crime of extortion under color of official right. The description includes an account of the unusual history of the Hobbs Act as an "ethics in government" statute. Part II criticizes the emerging majority view and argues that the Hobbs Act requires an act of inducement. The comment also presents a standard for determining what acts constitute inducement.

\section{CURRENT INTERPRETATIONS}

A. Prosecutions of Public Officials Under the Hobbs Act: Teaching an Old Law New Tricks

Although enacted in $1946,{ }^{8}$ the Hobbs Act did not assume its role as an "ethics in government" statute until almost thirty years later. ${ }^{9}$ Neither the legislative history of the Hobbs Act nor that of its predecessor contains a specific reference to the prosecution of public officials. ${ }^{10}$ Instead the Act was intended to prohibit certain labor activities, as a replacement for anti-racketeering provisions passed in 1934..$^{11}$ The Supreme Court had held in 1942 that those provisions did not reach union bullying of farmers. ${ }^{12}$ Congress enacted the Hobbs Act primarily to fill that gap. ${ }^{13}$

${ }^{8}$ Hobbs Act, ch. 645, $\S 1951,62$. Stat. 793 (1946) (codified as amended at 18 U.S.C. $\S 1951$ (1982)).

- The first successful Hobbs Act prosecution for extortion under color of official right was United States v. Kenny, 462 F.2d 1205 (3d Cir.), cert. denied, 409 U.S. 914 (1972).

${ }^{10}$ See S. REP. No. 1516, 79th Cong., 2d Sess. 1 (1946) (committee report on the Hobbs Act); H.R. Rep. No. 238, 79th Cong., 1st Sess. 1-2, 9 (1945) (same); 92 Cong. Rec. 7308 (1946) (Senate passage of Hobbs Act); 91 Cong. Rec. 11,899-922 (1945) (House passage of Hobbs Act); S. REP. No. 532, 73d Cong., 2d Sess. 1-2 (1934) (committee report on Anti-Racketeering Act); H.R. REP. No. 1833, 73d Cong., 2d Sess. 1-2 (1934) (same); 78 Cong. Rec. 11,482 (1934) (Senate accepts House amendments to Anti-Racketeering Act); 78 CoNG. REc. 11,402-03 (1934) (House passage of Anti-Racketeering Act); 78 CoNG. REc. 5734-35 (1934) (Senate passage of Anti-Racketeering Act).

${ }^{11}$ Act of June 18, 1934, ch. 569, 48 Stat. 979 (repealed 1946). The anti-racketeering provisions did not use the word extortion to define the proscribed conduct, but instead used the terminology of the common law offense by stating that any person who "[o]btains the property of another, with his consent, induced by wrongful use of force or fear, or under color of official right" shall be guilty of a felony. Id. at 980 .

12 United States v. Local 807, Int'l Bhd. of Teamsters, 315 U.S. 521 (1942).

1s See, e.g., 91 Cong. Rec. 11,900 (1945) (statement of Rep. Hancock) ("[T]his bill is made necessary by the amazing decision of the Supreme Court in the case of the United 
Several factors laid a foundation for federal prosecutors to use the Hobbs Act against corrupt state and local officials. ${ }^{14}$ First, the legislative history of the Act, while focusing on labor-related issues, indicates that anyone can be prosecuted for interfering with interstate commerce in ways the Act forbids. ${ }^{15}$ Second, the Hobbs Act's language invites its application to all public officials because it repeats the elements of the common law crime of extortion under color of official right. ${ }^{16}$ Third, the Supreme Court endorsed an expansive reading of the Act by reasoning that it "speaks in broad language, manifesting a purpose to use all the constitutional power Congress has to punish interference with interstate commerce by extortion."17 The Act's broad jurisdictional reach allows federal prosecutions for even minor interferences with interstate commerce. $^{18}$

States against Teamsters' Union 807 . . . That decision . . . legalizes in certain labor disputes the use of robbery and extortion.").

14 Several other federal laws are used in prosecutions of state and local officials: (1) The Travel Act, 18 U.S.C. $\S 1952$ (1982), which proscribes interstate travel for the purposes of extortion or bribery; (2) The Racketeering Influenced and Corrupt Organization Act (RICO), 18 U.S.C. $\$ \$ 1961-68$ (1982), which makes illegal one's engagement in an enterprise that affects interstate commerce through a pattern of racketeering activity; (3) The Mail Fraud Statute, 18 U.S.C. $\$ 1341$ (1982), which proscribes the use of the mails in schemes to obtain money fraudulently; (4) The Wire Fraud Statute, 18 U.S.C. § 1343 (1982), which proscribes the use of telephones or telegraphs in a scheme to defraud; and (5) The Internal Revenue Code, 26 U.S.C. $\$ \S 7201-16$ (1982), which proscribes attempts to evade federal taxes and make false statements on returns. For a review of the various federal statutes used to prosecute state and local officials for corruption, see JoHN T. NooNaN, JR., BriBEs 587-98 (1984); Henderson, The Expanding Role of Federal Prosecutors in Combating State and Local Political Corruption, 8 Cum. L. Rev 385 (1977). Prosecutions of federal officials for corruption are brought under 18 U.S.C. $\$ 201$ (1982). For a description of the various federal statutes dealing with white collar crime, see Project, Third Annual Survey of White Collar Crime, 22 Am. CrIm. L. REv. 279 (1985).

1s See, e.g., 91 Cong. REc. 11,911 (1945) (statement of Rep. Springer) ("I state that there is nothing in [the Hobbs Act] which relates to labor. Labor is not mentioned in the bill. It applies to every American citizen."). That the law does apply to everyone was firmly established in United States v. Culbert, 435 U.S. 371, 374-78 (1978).

${ }^{16}$ Cf. Bianchi v. United States, 219 F.2d 182, 193 (8th Cir.) (for the common law offense of extortion, the public official's color of office takes the place of force, threats, and pressure normally required to prove extortion), cert. denied, 349 U.S. 915 (1955).

17 Stirone v. United States, 361 U.S. 212, 215 (1960).

1818 U.S.C. § 1951(a) (1982). To invoke federal jurisdiction under the Hobbs Act, a prosecutor need show only a de minimis interference with interstate commerce. See, e.g., United States v. DeMet, 486 F.2d 816, 822 (7th Cir. 1973), cert. denied, 416 U.S. 969 (1974). As a practical matter, federal prosecutions were justified by assertions that local prosecutors were unwilling or unable to prosecute. See J. Noonan, supra note 14, at 600-01; Stern, Prosecutions of Local Political Corruption Under the Hobbs Act: The Unnecessary Distinction Between Bribery and Extortion, 3 Seton Hall L. Rev. 1, 1, 6 (1971). This comment will not delve into the federalism issues raised by legislation such as the Hobbs Act that is passed pursuant to the commerce clause yet serves a police function. 
With that foundation, federal prosecutors turned the Hobbs Act against state and local corruption during the 1960s. ${ }^{19}$ At first they had trouble prosecuting public officials under the proscription against extortion by "wrongful use of actual or threatened force, violence, or fear" because the subtlety and sophistication of corruption made it difficult to prove that the officials had created duress. $^{20}$ To get around this difficulty, federal prosecutors began to bring charges under the alternative proscription of extortion "under color of official right."

This tack initially appeared no better for prosecutors. Even prosecutions for extortion "under color of official right" seemed to require a showing that the official actively coerced the payment. Some courts believed that the legislative history of the Hobbs Act required its provisions to be governed by the New York law of extortion. ${ }^{21}$ According to New York law, the crimes of extortion and

10 Federal prosecutors have played a leading role in fighting state and local governmental corruption. See George Amick, The American Way of Graft 223 (1976) ("The most significant breakthrough in the war on state and local government corruption has been made by the federal prosecutors. . . . [B]ringing a zeal and sense of righteous outrage to their job, these new-breed D. A.'s have wrought a revolution in the Newarks and Jersey Citys and Chicagos and Baltimores and Charlestons of the country."). Several commentators have speculated on the social forces that spawned the dramatic increase in prosecutions of public officials. See J. Noonan, supra note 14, at 598 ("The dynamic movement to prosecute corrupt officials antedated Watergate. The movement, already perceptible under Nixon, was not markedly partisan . . . . So steady a development owed its power not as much to individual initiative as to the values dominant in the society."). Noonan offers several hypotheses to explain the rise in prosecutions, including diverse sociological and anthropological theories, but concludes that none is clearly proven by the evidence. Id. at 598-600. Another commentator argues that corruption represents a discrepancy between the myth of how the political system works and its real operational code. W. Michaed Reisman, Folded Lies 5661 (1979). Crusades against corruption, Reisman states, have the function of reaffirming the myth system. Id. at 98.

${ }^{20}$ See Ruff, supra note 1, at 1177 ("As prosecutors delved deeper into local corruption, however, they encountered a level of sophistication in the making and receiving of illicit payments which promised substantial difficulty in establishing the commission of extortion by duress. . . . [There were cases of implicit] understanding[s], difficult of proof, between contractors and officials concerning the need for payment in exchange for government contracts."); cf. Stern, supra note 18, at 6 ("[I]n the final stages of political corruption a local official may not even need to solicit the kickback, much less demand it. The practice at that stage may be so widespead and so well known that everyone contemplating doing business with that particular governmental body anticipates that he will have to 'take care of the boys downtown." ") (emphasis in original).

${ }_{21}$ See United States v. Addonizio, 451 F.2d 49, 72 (3d Cir.), cert. denied, 405 U.S. 936 (1972); United States v. Kubacki, 237 F. Supp. 638, 641-42 (E.D. Pa. 1965). These decisions relied on United States v. Nedley, 255 F.2d 350 (3d Cir. 1958), which concluded from evidence in the legislative history that New York law was the model for the Hobbs Act. Id. at 355. The legislative history contains considerable evidence that Congress intended to incorporate New York law into the Hobbs Act. See, e.g., 91 Cong. REc. 11,900 (1945) (The Hobbs Act "contains definitions of robbery and extortion which follow the definitions contained in 
bribery were mutually exclusive, ${ }^{22}$ so any crime constituting bribery fell outside the reach of the Hobbs Act. Since the principal difference between bribery and extortion was that extortion alone involved duress, officials could defend against Hobbs Act charges by claiming that the payment was made voluntarily-i.e., that it was actually a bribe. ${ }^{23}$ In this situation, the prosecutors faced a dilemma: without evidence of duress, their only alternative was to rely on the federal bribery law, ${ }^{24}$ which was ineffective unless the official had traveled in interstate commerce in connection with the bribe, an unlikely circumstance in most corruption cases. ${ }^{25}$

The prosecutors' dilemma was soon resolved. In 1972, the first conviction for extortion under color of official right was affirmed in United States v. Kenny. ${ }^{26}$ In Kenny, the Third Circuit held that because the wording of the Hobbs Act's proscription against extortion uses the disjunctive or, the Act permits prosecutions based solely on the "under color of official right" clause. ${ }^{27}$ More important, the court held that the language of the Hobbs Act embodied the common law offense of extortion under color of official right,

the laws of the State of New York.") (statement of Rep. Hancock).

This interpretation of the Act was by no means unanimous. For example, in arguing against the conclusion in Nedley, Stern marshaled four separate arguments. See Stern, supra note 18, at 2-3, 12-13. First, he argued that the references to New York law were made to appease representatives from that state who were opposed to the Hobbs Act. Id. at 2-3. Second, he stated that the language of the Act was meant to borrow from the common law as embodied in state statutes. Id. at 13; see also 91 CoNG. Rec. 11,910 (1945) (statement of Rep. Robison) (the definition of extortion is "that followed . . . generally throughout the Nation, in all the jurisdictions of the various states"). Third, Stern pointed out that it is unlikely that Congress meant New York law on the mutual exclusivity of extortion and bribery to be the law of the land because many of the New York cases developing the exclusivity doctrine were decided after the Act was passed. Stern, supra note 18, at 13; cf. United States v. Kahn, 472 F.2d 272 (2d Cir.) (modern trend is away from mutual exclusivity of extortion and bribery), cert. denied, 411 U.S. 982 (1973); MODEL PENaL CoDE § 223.4, at 217 (Official Draft \& Revised Comments 1980) (same transaction may be both extortion and bribery). Finally, Stern argued that because the Hobbs Act's language was not identical to the New York law against extortion, Congress had not intended to copy New York law exactly. Stern, supra note 18, at 12-13.

${ }_{22}$ People v. Dioguardi, 8 N.Y.2d 260, 273, 168 N.E.2d 683, 692, 203 N.Y.S.2d 870, 882 (1960) (" the essence of bribery is the voluntary giving of something of value to influence the performance of official duty', whereas the essence of extortion is 'duress' ") (emphasis in original) (quoting Hornstein v. Paramount Pictures, Inc., 22 Misc. 2d 996, 1003, 1006, 37 N.Y.S.2d 404, 412-13, 415 (Sup. Ct. 1942)); see also Addonizio, 451 F.2d at 72; Kubacki, 237 F. Supp. at 641 .

23 The defendant in Kubacki successfully proved this defense. See 237 F. Supp. at $641-$ 42; see also Ruff, supra note 1, at 1184-86; Stern, supra note 18, at 3-8.

24 The Travel Act, 18 U.S.C. \& 1952 (1982), discussed briefly supra note 14.

${ }^{25}$ See Stern, supra note 18, at 9-12.

28462 F.2d 1205 (3d Cir.), cert. denied, 409 U.S. 914 (1972).

27 Id. at 1229. 
thereby allowing the court to use authorities other than New York law to interpret the Act. ${ }^{28}$

Using common law authorities, the Kenny court said that an official commits the crime of extortion under color of official right when he takes property that is not due him. ${ }^{29}$ The court did not require that the official have committed acts creating fear or duress, but argued instead that the public office itself provides the coercion. ${ }^{30}$ The holding thus implied that the crimes of extortion and bribery could overlap, since even a person "voluntarily" paying an official could be influenced by the coercive force of the office.

What the Third Circuit had implied in Kenny, the Seventh Circuit soon made explicit in United States $v$. Braasch. ${ }^{31}$ Noting that the "use of office to obtain payments is the crux of the statutory requirement of "under color of official right," the Seventh Circuit held that an official need not falsely claim an official right to the payment; it was sufficient for conviction that the payment be made in connection with the official's public capacity. ${ }^{32}$ Finally, laying to rest the issue of the mutual exclusivity of extortion and bribery, the court declared "[ $t]$ hat such conduct may also constitute 'classic bribery' is not a relevant consideration."

Subsequently, the circuit courts have embraced the holdings of Kenny and Braasch. ${ }^{34}$ The validity of prosecutions based solely

${ }^{28}$ Id. The substitution of common law precedents for New York precedents was a twofold victory for Herbert J. Stern, the prosecutor in Kenny and author of the article cited supra note 18. In his article, published before Kenny, Stern argued what he later argued to the court-that the proper guide to interpreting the Hobbs Act was the common law. See Stern, supra note 18, passim; supra note 21. But see United States v. Furey, 491 F. Supp. 1048,1062 (E.D. Pa.) (holding after Kenny that New York law governs intent under the Hobbs Act), aff'd, 636 F.2d 1211 (3d Cir. 1980).

${ }^{29}$ Kenny, 462 F.2d at 1229.

${ }^{30}$.Id.; see also United States v. Sutter, 160 F.2d 754, 756 (7th Cir. 1947) (The common law offense of extortion under color of official right did not conform to the "ordinary meaning and understanding" of extortion, which requires some form of threat or duress. Instead, "color of public office took the place of . . f force, threats, or pressure.") (dictum).

${ }^{31} 505$ F.2d 139 (7th Cir. 1974), cert. denied, 421 U.S. 910 (1975).

32 Id. at 151 .

${ }^{33}$ Id. (footnote omitted).

${ }^{34}$ See, e.g., United States v. Hathaway, 534 F.2d 386, 393 (1st Cir.), cert. denied, 429 U.S. 819 (1976); United States v. Trotta, 525 F.2d 1096, 1100 (2d Cir. 1975), cert. denied, 425 U.S. 971 (1976); United States v. Mazzei, 521 F.2d 639, 644-45 (3d Cir.) (en banc), cert. denied, 423 U.S. 1014 (1975); United States v. Price, 507 F.2d 1349, 1350 (4th Cir. 1974); United States v. Williams, 621 F.2d 123, 124-25 (5th Cir. 1980), cert. denied, 450 U.S. 919 (1981); United States v. Harding, 563 F.2d 299, 302-07 (6th Cir. 1977), cert. denied, 434 U.S. 1062 (1978); United States v. Price, 617 F.2d 455, 457 (7th Cir. 1979); United States v. Brown, 540 F.2d 364, 371-72 (8th Cir. 1976); United States v. McClelland, 731 F.2d 1438, 1439-40 (9th Cir. 1984), cert. denied, 105 S. Ct. 2708 (1985); United States v. Hall, 536 F.2d 
on the "under color of official right" clause is now firmly established. The controlling force of the common law for interpretation and the overlap of the crimes of extortion and bribery are also accepted. $^{35}$ The result is that a long-dormant clause in the Hobbs Act has become a potent weapon for fighting corruption in state and local government.

However, a crucial question about the actus reus of extortion under color of official right remains to be answered: must an official induce payments, or is it sufficient merely to accept property not due him? Phrased another way, does an official commit extortion every time he accepts a bribe, or only when he has somehow induced the bribe?

\section{B. The Emerging Majority View}

A majority of the circuit courts that have considered the issue hold that an official commits extortion under color of official right by merely accepting or receiving property not due him. ${ }^{36}$ Under this view, the public official need not induce the payments or initiate the transaction. ${ }^{37}$ The mere acceptance of an unsolicited bribe

313, 320-21 (10th Cir.), cert. denied, 429 U.S. 919 (1976); United States v. Swift, 732 F.2d 878, 880 (11th Cir. 1984), cert. denied, 105 S. Ct. 905 (1985). The D.C. Circuit has not addressed this issue because prosecutions of public officials in the District of Columbia, like prosecutions of federal officials, fall under the federal bribery statute, 18 U.S.C. $\S 201$ (1982).

ss See, e.g., United States v. Hedman, 630 F.2d 1184, 1195 \& n.4 (7th Cir. 1980), cert. denied, 450 U.S. 965 (1981); United States v. Harding, 563 F.2d 299, 304-05 (6th Cir. 1977), cert. denied, 434 U.S. 1062 (1978); cf. United States v. O'Grady, 742 F.2d 682, 686-87 (2d Cir. 1984) (en banc) (rejecting an argument that some form of duress is required, thus effectively holding that some transactions can be both extortion and bribery).

so The courts are unanimous about the other two elements of the crime:

(1) The public official must intend to do the act constituting the crime. See, e.g., United States v. Warledo, 557 F.2d 721, 729 n.3 (10th Cir. 1977); United States v. Green, 246 F.2d 155, 159-60 (7th Cir.), cert. denied, 355 U.S. 871 (1957); United States v. Furey, 491 F. Supp. 1048, 1061-62 (E.D. Pa.), aff'd 636 F.2d 1211 (3d Cir. 1980); cf. United States v. Scacchetti, 668 F.2d 643, 649 (2d Cir.) (requiring an intent to obtain property by the use of the power and authority of public office), cert. denied, 457 U.S. 1132 (1982); United States v. Sweeney, 262 F.2d 272, 275 n.3 (3d Cir. 1959) (requiring criminal intent).

(2) The party making the payment must be motivated by a reasonable belief in the official's power. See, e.g., United States v. Brown, 540 F.2d 364, 372 (8th Cir. 1976). The public official need not have actual authority over the affairs of concern to the party making the payment; there need only be a reasonable belief that such influence exists. See, e.g., United States v. Meyers, 529 F.2d 1033, 1037 (7th Cir.), cert. denied, 429 U.S. 894 (1976); United States v. Mazzei, 521 F.2d 639, 643-44 (3d Cir.) (en banc), cert. denied, 423 U.S. 1014 (1975); see also United States v. Braasch, 505 F.2d 139, 151 (7th Cir. 1974) ("So long as the motivation for the payment focuses on the recipient's office, the conduct falls within the ambit of [the Hobbs Act]."), cert. denied, 421 U.S. 910 (1975).

${ }^{37}$ See United States v. Swift, 732 F.2d 878, 880 (11th Cir. 1984), cert. denied, 105 S. Ct. 
constitutes extortion under color of official right. ${ }^{38}$

The circuit courts offer two major reasons for this holding. First, building on Kenny's use of the common law to interpret the Hobbs Act, the courts give a very expansive reading to the common law offense of extortion under color of official right. ${ }^{39}$ Blackstone defined the common law offense as "an abuse of public justice, which consists in any officer's unlawfully taking, by colour of his office, from any man, any money or thing of value that is not due to him."40 The Supreme Court has explicitly followed Blackstone's statement of the common law offense, except that the Court's reading substitutes the verb obtain for take.41 The lower courts that do not require inducement define the terms take and obtain as synonyms of receive and accept. ${ }^{42}$ Their view of the common law offense thus includes even the passive acceptance of a bribe.

Second, the courts not requiring inducement support their holding by referring to the opinion in Braasch. ${ }^{43}$ There the Seventh Circuit stated:

It matters not whether the public official induces payments to perform his duties or not to perform his duties, or even, as here, to perform or not to perform acts unrelated to his duties which can only be undertaken because of his official position. So long as the motivation for the payment focuses on the recipient's office, the conduct falls within the ambit of [the Hobbs Act]. ${ }^{44}$

The courts apparently read the first sentence as doing away with

905 (1985); United States v. McClelland, 731 F.2d 1438, 1439-40 (9th Cir. 1984), cert. denied, 105 S. Ct. 2708 (1985); United States v. Jannotti, 673 F.2d 578, 594-96 (3d Cir.) (en banc), cert. denied, 457 U.S. 1106 (1982), and cert. denied, 105 S. Ct. 243 (1984); United States v. Hedman, 630 F.2d 1184, 1195 (7th Cir. 1980), cert. denied, 450 U.S. 965 (1981); United States v. Butler, 618 F.2d 411, 417-18 (6th Cir.), cert. denied, 447 U.S. 927 (1980), and cert. denied, 449 U.S. 1089 (1981). One other circuit has explicitly reserved the question. See United States v. Jarabek, 726 F.2d 889, 904 n.16 (1st Cir. 1984).

${ }^{38}$ See, e.g., Jannotti, 673 F.2d at 594-95; cf. Butler, 618 F.2d at 417-18 ("a showing that the motivation for the payment focuses on the recipient's office, regardless of who induces the payments, is sufficient to convict under the Hobbs Act").

${ }^{39}$ See, e.g., Jannotti, 673 F.2d at 594-95; Butler, 618 F.2d at 418.

104 William Blackstone, Commentaries *141, quoted in Jannotti, 673 F.2d at 595.

41 See United States v. Nardello, 393 U.S. 286, 289 (1969).

42 See, e.g., cases cited supra note 38.

${ }^{43}$ See, e.g., McClelland, 731 F.2d at 1439; Hedman, 630 F.2d at 1195; Butler, 618 F.2d at 420; cf. O'Grady, 742 F.2d at 689 (Braasch "explicitly rejected the notion that proof of inducement is necessary").

"Braasch, 505 F.2d at 151. 
the requirement of inducement, and the second as placing the focus of a trial on the motive of the payor, not of the official. ${ }^{45}$

The net result of this reading of the Act is that an official need not perform an act of inducement in order to commit extortion under color of official right. The official need only receive a payment, and the payor may initiate the transaction. In essence, the actus reus of committing extortion becomes indistinguishable from the actus reus of receiving a bribe; the Hobbs Act becomes the federal law against extortion and bribery. ${ }^{46}$

\section{The Minority View}

The first major deviation from the trend to ever broader interpretation of the crime of extortion under color of official right came in the Second Circuit's en banc decision in United States $v$. O'Grady. ${ }^{47}$ There the court held that it is not extortion "when a public official merely accepts unsolicited benefits knowing that they were given because of his public office." ${ }^{48}$ Instead, the official must actually do something to induce the payments. ${ }^{49}$ The court also required that the extortion "begin[] with the public official, not with the gratuitous actions of another." 50

The court offered two reasons for holding that an act of in-

45 A better reading of this passage would be that the nature of the act to be performed by the official in exchange for payment is irrelevant as long as the official uses the office to motivate or coerce the payment. Under this reading, the inquiry focuses on whether, not how, the official has used the office to induce payment. See infra note 86.

16 See J. Noonan, supra note 14, at 584-87 (the Hobbs Act extortion decisions, beginning with Kenny and Braasch, led to the equation of extortion and bribery, converting the Hobbs Act into a bribery statute and effectively federalizing the law of bribery).

17742 F.2d 682 (2d Cir. 1984) (en banc).

48 Id. at 684.

19 Id. at 687. In United States v. Paschall, 772 F.2d 68 (4th Cir. 1985), the Fourth Circuit appeared to follow O'Grady by holding that inducement was required, then essentially followed the majority by defining inducement so broadly as to make the requirement almost meaningless. The court observed that the requirement of inducement "springs directly from the statutory definition of extortion." Id. at 72. However, Paschall then held that officials' positions themselves were "invitations to seek [the officials'] goodwill by extending to them substantial favors which were not their due." Id. at 73. The court thus criminalized every case where an official receives a gift not due him, except where the gifts have less than "substantial value." Id. But see infra note 55 (arguing against this conclusion).

In another case decided after $O^{\prime} G r a d y$, the Seventh Circuit reaffirmed its position in United States v. Hedman, 630 F.2d 1184 (7th Cir. 1980), cert. denied, 450 U.S. 965 (1981), that inducement is not required to prove extortion under color of official right under the Hobbs Act. United States v. Schmidt, 760 F.2d 828, 832-33 (7th Cir.), cert. denied, 106 S. Ct. 86 (1985).

so O'Grady, 742 F.2d at 691. 
ducement is essential to a Hobbs Act prosecution. First, the court believed that Congress's enactment of a separate statute forbidding federal officials to accept gratuities" was "a clear indication that Congress did not believe that the Hobbs Act prohibits such conduct." ${ }^{22}$ The court reinforced its interpretation by noting that the federal gratuities law provided lower penalties than those in the Hobbs Act. ${ }^{33}$

Second, the court found that a requirement of inducement was necessary to protect public officials from what otherwise is an overbroad statute. The court asserted that without the requirement of inducement the Hobbs Act would be in effect a "professional ethics standard" that imposes on officials a duty never to accept gratuities. ${ }^{54}$ The court thought it unwise to equate extortion with lobbying efforts to "persuade, cajole or appease" public officials by giving small gratuities. ${ }^{55}$ Such an equation would place "every public official in jeopardy by virtue of his status rather than his venal acts." 58 The court also observed that an inducement requirement was necessary to prevent an impermissible degree of prosecutorial discretion. Without the requirement, the Hobbs Act "raises serious constitutional questions of fair notice and overbreadth and makes a mockery of the principle that criminal statutes must be construed strictly with any ambiguity resolved in favor of lenity."57

s1 18 U.S.C. $\$ 201(\mathrm{~g})$ (1982).

s2 O'Grady, $742 \mathrm{~F} .2 \mathrm{~d}$ at 691 . However, the dissenting opinion rebuts this argument by suggesting that the existence of overlapping statutes is "the inevitable product of piece-meal additions to the Code over the last 150 years," and is not a clear indicator of congressional intent. Id. at 707-08 (Mansfield, J., dissenting); cf. supra note 14 (discussing federal statutes that also overlap).

ss 742 F.2d at 691 . The argument based on different penalties is weak. The Hobbs Act had high penalties to provide appropriate punishment for the range of offenses proscribed, which included forcible extortion and violent robbery. Id. at 708 (Mansfield, J., dissenting). However, judges are not obligated to impose the maximum penalty; they can give a smaller penalty where a person is convicted of extortion equivalent to bribery under the Hobbs Act.

${ }^{54}$ Id. at 687 (majority opinion).

${ }^{\text {ss } I d}$. at 693. There is no statutory reason to exclude small payments from the reach of the law. The Hobbs Act proscribes interference with interstate commerce "in any way or degree," 18 U.S.C. $\$ 1951$ (a) (1982), thus indicating that even small payments fall within its reach. This is the major flaw in Judge Mansfield's suggested interpretation of the Act in O'Grady, 742 F.2d at 708-09 (Mansfield, J., dissenting) (arguing that culpability should hinge on the size of the payment).

s8 742 F.2d at 693 (majority opinion); cf. Robinson v. California, 370 U.S. 660, 666 (1962) (overturning laws criminalizing narcotics addiction on the ground that they punish a status rather than an act). The court's statement that the Hobbs Act would create a "status offense" is not an accurate characterization of the majority view. An official would be jeopardized by his status only if the receipt of gratuities were an inherent aspect of being a public official.

${ }^{67} 742 \mathrm{~F} .2 \mathrm{~d}$ at 694 . The court's allusions to the constitutional doctrines of vagueness 
The court then set forth some guidelines for determining what constitutes inducement under the Hobbs Act. First, the court subscribed to a general definition of "induce": "to move and lead (as by persuasion or influence)." ${ }^{\prime 38}$ Second, the court stated that the official must initiate the transaction. ${ }^{59}$ Third, the court indicated that although the official must do something to induce the payments, there is no requirement that the official grant or carry out favors: no quid pro quo is necessary. ${ }^{60}$ Finally, the court stated that the requisite act of inducement could take the form of words or deeds and could be quite subtle, as long as the act creates the impression that payments are expected. ${ }^{61}$ Judge Pierce suggested in his concurring opinion that a pattern of receiving payments could "constitute a communicative act" from which inducement might be inferred. ${ }^{62}$

\section{The Requisite Act of Inducement}

A close reading of the Hobbs Act shows that the Second Circuit's conclusion is correct: to commit extortion under color of official right an official must somehow affirmatively induce a payment not due him. However, inducement should be defined to include all acts that create an expectation of payment, both subtle and blatant, regardless of whether the official originally took the initiative.

and overbreadth can be criticized. As to vagueness, the law as other circuits have interpreted it is not vague. It provides a very clear guide to conduct. As $O^{\prime} G r a d y$ itself states, the interpretation imposes an affirmative obligation not to accept any gifts. Id. at 687. In addition, the court's reference to overbreadth appears inappropriate. Courts usually refer to overbreadth as a constitutional matter only when a law implicates first amendment interests. See Laurence Tribe, American Constitutional Law § 12-24, at 711 (1978) ("A plausible challenge to a law as void for overbreadth can be made only when (1) the protected activity is a significant part of the law's target, and (2) there exists no satisfactory way of severing the law's constitutional from its unconstitutional applications so as to excise the latter clearly in a single step from the law's reach.") (emphasis in original). O'Grady does not discuss first amendment implications, but the Hobbs Act arguably survives the first part of Tribe's test because no protected activity is a significant part of the law's target. But see infra note 103.

ss O'Grady, 742 F.2d at 688 n.8 (quoting Webster's ThIRd New International DicTIONARY 1154 (1961)).

so 742 F.2d at 691.

so Id. at $688-89$.

61 Id. at 691-92.

${ }^{62}$ Id. at 694 (Pierce, J., concurring). Although this concurrence received the votes of the majority of the en banc panel, three judges who did not favor the pattern-of-receipt theory voted for it solely out of concern for sound judicial administration; they felt it important to have a majority direction to the trial court for composing jury instructions at the new trial. The panel had previously been divided five to five on the issue. Id. at 694-95 (Newman, J., concurring). 
This approach properly restores the prosecutor's burden of demonstrating a culpable act, but does not allow that burden to immunize conduct that Congress intended the Hobbs Act to reach.

\section{A. The Case for Requiring an Act of Inducement}

Several considerations are relevant to interpreting the Hobbs Act: (1) the plain meaning of the statute; (2) congressional intent, as revealed by the purpose of the Act and its historical sources; (3) the principle of fair notice, which requires that ambiguous criminal statutes be strictly construed in favor of the defendant; and (4) the effect of any interpretation on prosecutorial discretion.

1. Statutory Language. The Hobbs Act defines extortion as "the obtaining of property from another, with his consent, induced by wrongful use of actual or threatened force, violence, or fear, or under color of official right."63 According to traditional methods of statutory interpretation, this definition should be read both in reference to the plain meaning of the words ${ }^{64}$ and in such a way as to give effect to all the words of the statute..$^{65}$

The plain meaning of obtaining indicates that the Hobbs Act requires an act by a public official designed to encourage a payment. The verb obtain suggests action by the obtainor-in this case, effort by the official to procure money not due him. Black's Law Dictionary defines obtain as "[t]o get hold of by effort; to get possession of; to procure; to acquire, in any way." phrase in the definition explicitly requires effort by the obtainor. The other aspects of the definition, especially the references to procure and acquire, reinforce that requirement. Procure, for instance, means " $[t]$ o initiate a proceeding; to cause a thing to be done; to instigate; to contrive, bring about, effect, or cause." ${ }^{\text {"67 }} \mathrm{Ac}$ quire generally means " $[t]$ o gain by any means, usually by one's own exertions." 68

Furthermore, Congress used obtaining elsewhere in the Hobbs Act in a context that clearly denotes effort to get property. The

${ }^{63} 18$ U.S.C. § 1951(b)(2) (1982) (emphasis added).

64 See, e.g., Bread Political Action Comm. v. Federal Election Comm'n, 455 U.S. 577, 580 (1982); Dawson Chem. Co. v. Rohm \& Haas Co., 448 U.S. 176, 187 (1980); W. LaFave \& A. Scott, Handbook on Criminal Law, $\S 10$, at 70 (1972).

${ }^{63}$ See, e.g., United States v. Menasche, 348 U.S. 528, 538-39 (1955).

${ }^{68}$ Black's Law Dictionary 972 (5th ed. 1979).

${ }^{67}$ Id. at 1087.

${ }^{68}$ Id. at 23. Corpus Juris Secundum also states that "the great weight of authority of lexicographers is to the effect that the strict and primary acceptation of the word 'obtain' is to acquire by one's own efforts." 67 C.J.S. Obtain (1978). 
sentence immediately preceding the definition of extortion defines robbery as "the unlawful taking or obtaining of personal property" against the will of another. ${ }^{69}$ Robbery cannot be conceived of as the passive acceptance of property. If Congress meant the words taking and obtaining to include passive acceptance, it would not have used those words to define such an active offense. Since it also seems natural to define the same words in the same way from sentence to sentence, no passive connotation should be given to taking and obtaining in the extortion section.

The grammatical structure of the Act also reinforces this reading. The word or functions in one of two ways in the definition of extortion. Courts holding that no inducement is necessary see or as creating a construct in which the preposition under parallels the verb induced: " 'extortion' means the obtaining of property from another, with his consent, . . . under color of official right."70 $\mathrm{Al}$ ternatively, courts requiring inducement read or as creating a construct in which the preposition under parallels the preposition by: " 'extortion' means the obtaining of property from another, with his consent, induced . . . under color of official right." "1

While the first reading could be forced upon the statutory lan-

69 18 U.S.C. $\$ 1951(\mathrm{~b})(1)$ (1982) (emphasis added). This section reads in full:

The term "robbery" means the unlawful taking or obtaining of personal property from the person or in the presence of another, against his will, by means of actual or threatened force, or violence, or fear of injury, immediate or future, to his person or property, or property in his custody or possession, or the person or property of a relative or member of his family or of anyone in his company at the time of the taking or obtaining.

Id.

Similarly, in Blackstone's definitions both of bribery and of extortion the crucial verb is take. See 4 W. Blackstone, supra note 40, at *139 (bribery); id. at *141 (extortion). But Blackstone also uses the verb take in his definition of robbery. Id. at *241 ("There must be a taking, otherwise it is no robbery.").

${ }_{70} 18$ U.S.C. $\$ 1951(b)(2)(1982)$. One court edits the statute in exactly this manner. See United States v. Jannotti, 673 F.2d 578, 594 (3d Cir.), cert. denied, 457 U.S. 1106 (1982), and cert. denied, 105 S. Ct. 243 (1984); see also O'Grady, 742 F.2d at 697 (Mansfield, J., dissenting).

${ }^{73}$ Significantly, commentary produced by the Justice Department appears to support this grammatical construction of the statute. See U.S. Dep'T of Justice, UNITED STATES ATTORNEYS' MANUAL § 9-131.180 (1984) ("[T]here is some question as to whether the Hobbs Act defines this type of extortion as 'the obtaining of property from another under color of official right,' or as 'the obtaining of property from another, with his consent, induced under color of official right.' . . . [T] The grammatical structure of the Hobbs Act would appear to support the latter language."). The Fourth Circuit also adopted this reading of the statute in United States v. Paschall, 772 F.2d 68, 71 (4th Cir. 1985), discussed supra note 49.

A third possible reading would parallel under and with: "extortion' means the obtaining of property from another . . . under color of official right." This reading is extremely unnatural, however, since it would edit out the important phrase, "with his consent." 
guage, only the second comports with standard American usage. As a coordinating conjunction, or is properly used to coordinate-that is, to create parallels among-two or more grammatically equivalent words, phrases, or clauses. ${ }^{72}$ For example, the first or in the Hobbs Act's definition of extortion coordinates (or creates a parallel between) two adjectives, actual and threatened. The second or coordinates three nouns, force, violence, and fear. In accordance with both reason and standard usage, the third or should be understood to coordinate the prepositional phrase beginning with under and another prepositional phrase. The second reading does coordinate the last prepositional phrase, "under color of official right," and the second to last prepositional phrase, "by wrongful use of." Also, under the second reading both phrases have a parallel function with respect to induced. In contrast, the first reading coordinates a verb, induced, and a preposition, under. The first reading has the additional irregularity of reading under as a preposition of obtaining, which is the verb form (gerund) farther from it than is the verb induced, a problem that does not arise with the second reading.

Ironically, the second reading finds some support in the very cases relied upon by courts that do not require inducement. In United States $v$. Kenny, ${ }^{73}$ the court approved a jury instruction that the payment could be "induced either by" fear or under color of official right. ${ }^{74}$ The instruction's use of the correlative conjunction either . . . or parallels the use of the coordinating conjunction or as interpreted by the courts requiring inducement. In United States $v$. Braasch, ${ }^{75}$ the court stated that "coercive extortion is not the only type [of extortion] outlawed by the Act. The other is inducing payoffs 'under color of official right' . . .." Bro Brasch's statement is similar to the second reading of the statute; both read "under color of official right" as a prepositional phrase relating to

22 See D. EbbitT \& W. Ebbitt, Index to English 78 (7th ed. 1982); B. Evans \& C. Evans, A Dictionary of Contemporary American Usage 112-13 (1957).

${ }^{73} 462$ F.2d 1205 (3d Cir.), cert. denied, 409 U.S. 914 (1972).

74 Id. at 1229.

76505 F.2d 139 (7th Cir. 1974), cert. denied, 421 U.S. 910 (1975).

${ }^{28}$ Id. at $151 \mathrm{n} .8$ (emphasis added); see also United States v. Paschall, 772 F.2d 68 (4th Cir. 1985), discussed supra note 49; United States v. Adcock, 558 F.2d 397, 403 (8th Cir. 1977) ("The government must establish that the defendant induced the victim to part with his money or property and that the defendant did so by extortion."); United States v. Hathaway, 534 F.2d 386, 394 (1st Cir. 1976) ("inducement had to come from the official"); United States v. Staszcuk, 502 F.2d 875, 877 (7th Cir. 1974) ("the obtaining of property from another, with his consent, induced . . . under color of official right"), aff'd in part and rev'd in part, 517 F.2d 53 (7th Cir.) (en banc), cert. denied, 423 U.S. 837 (1975). 
induced instead of to obtaining.

In light of these considerations, the language of the Hobbs Act should be read to proscribe only payments made after an act of inducement. ${ }^{77}$ The plain meaning of obtaining implies effort by the obtainor. In addition, the last or coordinates the prepositions by and under, leaving induced in the definition of extortion under color of official right. While the plain meaning of obtaining and the logical function of the last or each show independently that the Hobbs Act requires an official to induce payments to commit extortion under color of official right, the presence of both in the statutory definition of extortion under color of official right is as clear an indication of that requirement as one might hope to find in a statute.

2. Congressional Intent. The language of the Hobbs Act is clear about inducement precisely because Congress intended it to be an essential element of extortion. Although the legislative history of the Act sheds little light on the matter, the underlying intent manifests itself in the common law definition that the statute adopts, as well as in the historical context of the Act's passage.

The Hobbs Act adopts the elements of the common law offense of extortion, which typically required inducement. The language employed in the Hobbs Act mirrors the usual definitions of the common law offense. Authorities on the common law defined extortion as a public official taking, by color of office, payments not due him. ${ }^{78}$ The fact that Congress borrowed common law terms means that it "adopted the cluster of ideas that were attached to

37 Some contend that requiring inducement to prove extortion under color of official right would make the crime indistinguishable from extortion induced by fear or violence, rendering the "under color of official right" language surplusage. See United States v. Cerilli, 603 F.2d 415, 425 (3d Cir. 1979), cert. denied, 444 U.S. 1043 (1980). This view, however, assumes erroneously that there cannot be inducement without acts of actual or threatened force, violence, or fear. Certainly acts communicating encouragement to a prospective donor need not instill fear or amount to threats. See Note, Extortion "Under Color of Official Right": Federal Prosecution of Official Corruption under the Hobbs Act, 5 LoY. U. CHI. L.J. 513, 532 (1974) ("Common sense would dictate that some act on the part of the official apprising the victim of his desire to obtain money is probably the way such extortions would take place. This action by the official, however, does not have to rise to the level of a direct threat or overt coercion if done under color of official right.").

78 See 4 W. BLAcKstone, supra note 40, at *141; 35 C.J.S. Extortion $\$ 1$ (1960). The common law requirement that the payments must be "not due" the official is not discussed much in the cases. Presumably, an official must take payments not allowed by law. The relevant body of law would seem to be state and local law, since the offices are created by state and local law. Therefore, payments must be "not due" the official under state and local statutes regulating public offices. Thus, if a defendant could show that state and local law allowed the payment in question, the payment would be due him, and he would be acquitted. 
each borrowed word . . . unless otherwise instructed."79 Indeed, the legislative history shows that Congress was well aware of the origin of the language it used..$^{80}$ It is reasonable, then, to attribute to Congress the intention to subsume within the Hobbs Act the elements of common law extortion, even in the absence of other clear statements of purpose to that effect. ${ }^{81}$

Since the common law provides a guide to congressional intent, the relevant inquiry is whether inducement was an element of the common law offense of extortion under color of official right. The major cases explicitly applying the common law definition typically involved acts of inducement by the official. Those acts included, for example, a deputy collector of internal revenue's demand for additional tax money that he falsely said was due the government, and a borough attorney's demand for fifteen thousand dollars in exchange for his influence in getting a zoning ordinance passed..$^{82}$ As one court stated in rejecting a charge of extortion:

It is clear that neither the evidence nor the indictment in the case at bar presents a charge of extortion. [Another person] took the initiative, and was the active proponent of all that was done. All that [the defendant] did was to assent ostensibly to [the other person's] offer, and receive the money. ${ }^{83}$

79 Morrissette v. United States, 342 U.S. 246, 263 (1952); see also W. LAFAvE \& A. ScoTr, supra note $64, \S 10$, at 73-74.

so See 91 CoNG. REc. 11,910 (1945) (statements of Rep. Robison and Rep. Springer); id. at 11,906 (statement of Rep. Robison); id. at 11,912 (statement of Rep. Hobbs) ("Those words [robbery and extortion] have been construed a thousand times by the courts. Everybody knows what they mean."); id. at 11,914 (statement of Rep. Russell) ("Wherever jurisprudence has had its sway robbery and extortion have been defined. There is no use defining those terms because they are so well defined that their definition now is a matter of common knowledge.").

${ }^{81}$ In United States v. Kenny, 462 F.2d 1205 (3d Cir.), cert. denied, 409 U.S. 914 (1972), discussed supra notes $26-30$ and accompanying text, the court accepted the significance of the common law offense for interpretation, but did not explain why it chose that interpretative guide, except to say that the wording of the Hobbs Act repeats the common law offense. Id. at 1229.

${ }_{82}$ See United States v. Altmeyer, 113 F. Supp. 854, 856 (W.D. Pa. 1953) (deputy collector of internal revenue); State v. Weleck, 10 N.J. 355, 370-73, 91 A.2d 751, 758-60 (1952) (borough attorney).

${ }^{83}$ Daniels v. United States, 17 F.2d 339, 342 (9th Cir.), cert. denied, 274 U.S. 744 (1927). The Supreme Court's formulation of the common law offense of extortion utilizes the verb obtain, which connotes an active element. See United States v. Nardello, 393 U.S. 286, 289 (1969); supra notes 66-69 and accompanying text.

In contrast, Ruff views the common law offense as requiring more than inducement. Ruff contends that the theory in United States v. Sutter, 160 F.2d 754, 756 (7th Cir. 1947) cited in Kenny, 462 F.2d at 1229, that color of official right takes the place of the use of force, threats, or pressure under the common law offense is an "explanation wholly at odds with the true common law origins of the offense." Ruff, supra note 1, at 1182. But Ruff 
In addition, although the language used in the common law authorities might allow some overlap between the crimes of extortion and bribery, the two traditionally have been treated as separate offenses. ${ }^{84}$ The historic separation of the offenses implies that extortion and receipt of a bribe are not identical. "The distinction between bribery and extortion seems to be that the former offense consists in offering a present or receiving one, the latter in demanding a fee or present by color of office." 85 Requiring inducement as an element of extortion under color of official right would preserve this distinction between bribery and extortion; the passive acceptance of payments by a public official would be considered bribery, but not extortion. ${ }^{86}$

A final guide to the meaning of the common law offense is its historical context. The offense arose during times when public officials made their living largely by collecting fees from citizens.

offers no proof that the common law offense requires force, threats, or duress. Id. at 1179-81 (discussing common law offense). Moreover, Ruff's theory, if accepted, would render the entire "under color of official right" clause meaningless, since force, threats, or pressure would have to be proven in order to convict an official. Oddly, Ruff himself makes this point:

If one adopts the usual course and attempts to give meaning to all the statutory language, it is hard to challenge the result reached by the courts. Although it could be argued that the words "under color of official right" suggest one means of establishing the use of fear, this reading would reduce the words to surplusage . . . .

Id. at 1197.

${ }^{84}$ See J. Noonan, supra note 14, at 585-86; 4 W. Blackstone, supra note 40 , at *141 (extortion); id. at *139 (bribery).

${ }^{85}$ State v. Pritchard, 107 N.C. $921,929,12$ S.E. 50,52 (1890) (emphasis added).

${ }^{88}$ This is consistent with the position taken by the Model Penal Code, which states: "[T]he same transaction may well constitute both [extortion and bribery]. The difference between the two offenses is that extortion requires an element of intimidation that need not be present in the case of bribery." Model Penal Code $\$ 223.4$, at 217 (Official Draft \& Revised Comments 1980) (footnote omitted). Of course, if the office automatically supplies this element of intimidation, there would be no difference between the crimes. See United States v. Paschall, 772 F.2d 68 (4th Cir. 1985), discussed supra note 49.

Nothing in Kenny or Braasch is inconsistent with this position. Both cases involved clear acts of inducement, so neither case reached the issue of whether inducement is required. See United States v. Kenny, 462 F.2d 1205, 1210-11 (3d Cir.) (extortion from construction contractors involving demands), cert. denied, 409 U.S. 914 (1972); United States v. Braasch, 505 F.2d 139, 142 (7th Cir. 1974) (shakedowns by police of local businesses), cert. denied, 421 U.S. 910 (1975). And neither decision suggests that an act of inducement should not be required. The much quoted passage from the Braasch opinion, which is read as saying that inducement should not be required, see supra notes $43-45$ and accompanying text, has been misconstrued. The passage does not say that inducement is unnecessary; it says instead that the way the official induces payments is irrelevant as long as the office is the motivation for the payments. And the further statement in Braasch that conduct constituting extortion may also amount to bribery certainly does not mean that all conduct cognizable as bribery will also be extortion. That there is some overlap between extortion and bribery does not eliminate the distinction between the two crimes. 
Often those collections were regular and legal events. In this context, extortion under color of official right was an offense intended to prevent officials from taking fees to which they had no legal entitlement. In this way it was aimed at officials who abused the collection process and not at officials who passively accepted gratuities. ${ }^{87}$

This interpretation is also consistent with Congress's aims in passing the Hobbs Act. Congress was most concerned about active coercion by labor union members. The legislative history is replete with accounts of union members stopping farm produce trucks to coerce farmers into making payments to the union. ${ }^{88}$ Acts of robbery and extortion involving violence were the primary concern of the legislators. ${ }^{89}$ Thus, Congress was concerned exclusively with extortion of an active nature. So even if one could somehow ignore the inducement requirement that carried over from the common law offense of extortion under color of official right, the kind of actions Congress meant to target strongly suggests the same interpretation of the "under color of official right" clause.

3. The Principle of Fair Notice. One of the traditional protections for the accused in the American criminal justice system is the practice of construing criminal statutes so as to give the fairest possible notice of what acts they prohibit. ${ }^{90}$ The canon of interpretation which implements this policy states that criminal statutes

${ }^{87}$ See State v. Begyn, 34 N.J. 35, 46, 167 A.2d 161, 166 (1961) (purpose of the common law offense was "simply to penalize the officer who non-innocently insisted on a larger fee than he was entitled to or a fee where none was permitted or required"); R. PERkINs \& R. Boyce, Criminal Law 443 (3d ed. 1982) ("Common-law extortion is the corrupt collection of an unlawful fee by an officer under color of office .....").

ss See 91 CoNG. REc. 11,902 (statement of Rep. Walter); id. at 11,903 (statement of Rep. Gwynne); id. at 11,904 (statement of Rep. Anderson); id. at 11,905-06 (statement of Rep. Robison); id. at 11,907 (statement of Rep. Fellows); id. at 11,908 (statement of Rep. Vursell); id. at 11,911 (statement of Rep. Jennings); id. at 11,917 (statement of Rep. Rivers).

${ }^{89}$ See id. at 11,913 (statement of Rep. Whittington) ("The bill is to prevent a repetition of the physical violences by members of labor unions . . . . It pronounces the acts of those who assault and extort from the operators of trucks engaged in legitimate interstate commerce crimes with penalties.").

${ }^{\text {so }}$ See W. LAFAvE \& A. ScoTT, supra note $64, \S 10$, at 72 (in analyzing the issue of fair notice, the emphasis is on the wording of the statute); $i d$. at 74 (when the content of language from the common law has a clear meaning, courts will consider the common law when analyzing notice). Certain elements of the common law offense of extortion are sufficiently vague that the issue of fair notice is not resolved by resort to the common law. See United States v. O'Grady, 742 F.2d 682, 695 (2d Cir. 1984) (Van Graafeiland, J., concurring and dissenting) ("As is apparent from disparate judicial interpretations, the phrase 'under color of official right', standing alone, is vague almost to the point of unconstitutionality."). But see United States v. Trotta, 525 F.2d 1096, 1098 n.6 (2d Cir. 1975) (the term "under color of official right" is a legal term of art like the word "obscene"), cert. denied, 425 U.S. 971 (1976). 
should be strictly construed in favor of lenity to the defendant.91 To the extent that the Hobbs Act proscription admits of more than one meaning, construing the law to require an act of inducement is more lenient to the defendant since it adds to the burden of the prosecution. Public officials should not be made to suffer under the strictest possible reading of the Act if its language might be seen as ambiguous.

Of course, leniency has its costs. If prosecutors must prove an act of inducement, fewer culpable officials might be prosecuted under the Act. ${ }^{22}$ And to allow the defendant to deny any actual inducement of the payments could bring about the anomalous situation feared by federal prosecutors: an extortion charge could be defended by proof that the transaction was really a bribe..$^{93}$

But these fears are both inappropriate and exaggerated. First of all, the prosecutors' argument amounts to nothing more than a denial of the widely accepted principle of fair notice. The very existence of this principle makes plain that a fair criminal process is more important than high conviction rates. To favor leniency places Congress, and not courts or prosecutors, in the position of deciding the appropriate reach of criminal statutes. If reading the

1 See United States v. Mazzei, 521 F.2d 639, 665 (3d Cir.) (Gibbons, J., dissenting) (canon of interpretation dictating leniency is rooted in the principle of adequate notice), cert. denied, 423 U.S. 1014 (1975); W. LAFAVE \& A. ScoTT, supra note 64, § 10, at 72-73.

${ }^{22}$ Compare this problem of proof to the problems discussed supra notes 20-25 and accompanying text. It is difficult to determine which outcomes of past successful prosecutions for extortion under color of official right would be changed by requiring proof of an act of inducement. Most cases affirming convictions involve some facts suggesting inducement. See $O^{\prime} G r a d y, 742$ F.2d at 689, and cases cited therein. However, there is doubt about whether the evidence of inducement would have been sufficient to convict if inducement were explicitly required. In his dissent in O'Grady, Judge Mansfield noted:

If inducement clearly existed in those cases, no purpose would have been served by the flat, unequivocal and repeated pronouncements by these other circuits and even by ourselves to the effect that further proof of inducement is unnecessary as long as the benefits were bestowed upon the official because of his public office. . . . Had any of those courts construed the statute as it has been interpreted by the majority here they would have reversed and remanded for a new trial.

Id. at 706 (Mansfield, J., dissenting) (citations omitted).

${ }^{93}$ See Stern, supra note 18, at 2, 4, 7-8 (discussing the defense of bribery to a charge of extortion). The logic behind the opposition to this defense of bribery is that the defendant may escape simply because he was mischarged. But if extortion requires inducement, failure to prove that element should result in acquittal of extortion even if the defendant's actions clearly amount to some other crime. By analogy, a defendant who rebuts a first-degree murder charge by proving there was no premeditation should be acquitted of the charge. In doing this, however, the defendant may well have shown that the crime in fact was manslaughter. The mischarging problem can be solved through multiple charges. If it is difficult to use multiple charges because of the jurisdictional bases of the Hobbs Act and the Travel Act, see supra note 14 and text accompanying note 25 , that is hardly a reason to deny the defendant the opportunity to negate an element of the offense. 
Hobbs Act strictly in favor of defendants-and in light of its language and history-would allow conduct Congress wants to prohibit, then the Act should be amended..$^{94}$ Under vague statutes the benefit of the doubt belongs to the defendant and not to constantly changing notions of the efficient level of prosecution.

There is also no reason to believe that the additional burden on the prosecution will be unreasonable if inducement is required. Additional acquittals will result only where there is no proof that the official encouraged the payments in some way. Cases involving a pattern of receiving benefits, which were a major concern of those opposed to the defense of bribery, ${ }^{95}$ would still violate the Act, since inducement could be inferred from the pattern of receipt. $^{96}$ Defined in this way, an inducement requirement reasonably accommodates both the principle of fair notice and the interest in prosecuting government officials who betray the public trust.

4. Reducing Prosecutorial Discretion. Without a requirement of inducement, extortion under color of official right is an extremely broad offense, bringing a great deal of potentially unobjectionable conduct within the ambit of the Hobbs Act and reaching even the passive receipt of small gratuities by public officials. ${ }^{97}$ For example, public officials often receive benefits such as lunches or tickets to sporting events which are designed to "persuade, cajole or appease them."98 Officials in non-policymaking positions also receive benefits; for example, police officers commonly receive free food from restaurants while on duty. ${ }^{99}$ These practices are wide-

o4 If Congress wanted to reach the acceptance of all gifts and gratuities by state and local officials, the simplest way would have been to pass a bribery statute with jurisdiction based on interference with interstate commerce in even the slightest way. In fact, it is probably the jurisdictional limitations of the current federal bribery statute, The Travel Act, 18 U.S.C. § 1952 (1982), which prompted federal prosecutors to use the Hobbs Act for prosecutions of state and local officials. See supra text accompanying note 25.

Furthermore, the fact that Congress intended the Hobbs Act to reach all interferences with interstate commerce provides no reason to resolve the statute's ambiguity automatically in favor of the prosecution. The congressional intent evidenced by use of the common law definition of the offense should control. See supra notes 16, 78-86 and accompanying text.

is See Stern, supra note 18 , at 6.

${ }^{98}$ See United States v. O'Grady, 742 F.2d 682, 694 (2d Cir. 1984) (Pierce, J., concurring); infra notes 104-05 and accompanying text (discussing pattern of receipt giving rise to an inference of inducement).

97 This is a major theme of the O'Grady decision. See 742 F.2d at 693-94; supra notes 54-56 and accompanying text.

${ }_{98} O^{\prime}$ Grady, 742 F.2d at 693.

90 The example usually employed to illustrate the possible application of the Hobbs Act to the recipt of small gratuities is the tradition of giving a Christmas tip to mail carriers. See, e.g., United States v. Campo, 605 F. Supp. 886, 890 (S.D.N.Y. 1985). However, since 
spread and involve substantial sums, but they enjoy general acceptance. ${ }^{100}$

Interpreting the Hobbs Act so that inducement need not be proven would create vast potential for the selective prosecution of public servants for accepting even inconsequential or customary gifts. As for the argument that reasonable prosecutorial discretion will prevent abuse, ${ }^{101}$ there are two replies. First, the prosecution of public officials can be a tempting undertaking for federal prosecutors bent on establishing a reputation or gaining publicity. ${ }^{\mathbf{1 0 2}}$ Second, the ability to embroil a public official in criminal charges, even on trivial matters, can be a potent political weapon. These incentives to misuse such a broad range of discretion give good reason to curtail that discretion by interpreting the Act to require inducement. ${ }^{103}$

postal employees work for the federal government, prosecutions would be brought under 18 U.S.C. $\S 201$ (1982), instead of the Hobbs Act. Interestingly, 18 U.S.C. $\S 201(\mathrm{~g})$ (1982), which forbids the receipt of all gratuities by federal employees, appears to proscribe the traditional Christmas tip. See J. Noonan, supra note 14, at 698.

${ }^{100}$ See O'Grady, 742 F.2d at 693. The Model Penal Code states:

Payment to a public servant to induce performance of a non-discretionary act that he has a duty to perform without compensation ... is widespread ... and in many quarters it is tolerated quite openly. This suggests that community standards of behavior have not yet crystallized sufficiently to warrant imposition of criminal penalties for such behavior .... Accordingly, the primary means of controlling such conduct should be disciplinary action within the civil service.

Model Penal Code $\$ 240.1$, at 35-36 (Official Draft \& Revised Comments 1980).

${ }^{101}$ See O'Grady, 742 F.2d at 694 (discussing the government's position).

102 Indeed, a federal prosecutor might be encouraged to prosecute after examining the careers of past U.S. Attorneys who have successfully used the Hobbs Act to prosecute corrupt officials. Some examples include James Thompson, now governor of Illinois; Richard Thornburgh, now governor of Pennsylvania; and Herbert Stern, now a federal district judge in New Jersey.

${ }^{103}$ A separate but related issue concerning prosecutorial discretion under the extortion proscription of the Hobbs Act involves the possibility of prosecutions for extortion of campaign contributions. Extortion of contributions under color of official right has been held to be within the reach of the Hobbs Act. See United States v. Dozier, 672 F.2d 531, 537 (5th Cir.), cert. denied, 459 U.S. 943, (1982); United States v. Cerilli, 603 F.2d 415, 418-19 (3d Cir. 1979), cert. denied, 444 U.S. 1043 (1980); United States v. Trotta, 525 F.2d 1096 (2d Cir. 1975), cert. denied, 425 U.S. 971 (1976). With or without the requirement that a public official induce payments to be convicted of extortion under color of official right, much traditional political fundraising would appear to fall within the Hobbs Act extortion proscription.

Both judges and commentators have expressed concern over the application of the Hobbs Act to traditional political fundraising. See United States v. Barber, 668 F.2d 778, 783 (4th Cir.) (the Hobbs Act "could arguably prohibit a public official from personally soliciting a campaign contribution"), cert. denied, 459 U.S. 829 (1982); Cerilli, 603 F.2d at 437 (Aldisert, J., dissenting) (referring to the possible application of the Act to political fundraising and expressing fear of a Hobbs Act "run rampant"); Ruff, supra note 1, at 1196. Two courts have rejected vagueness challenges to the Hobbs Act's application to political 


\section{B. Fashioning a Standard of Inducement: A Proposal}

The previous section has shown that the Hobbs Act should be read as prohibiting only extortion that involves an act of inducement. The Act and its history, however, are silent about what kinds of acts constitute inducement. Hence the question: on what evidence may a jury infer that an official has induced payments in violation of the Act?

The purposes of the Hobbs Act are best served if inducement is defined as a communicative act or course of action intended to encourage a consensual transfer of property to the public official. The inducement may take the form of an explicit request, demand, ultimatum, or offer to perform a quid pro quo. Or, the inducement may be more subtle, in the form of statements or nonverbal expressions that implicitly request payment, as long as the public official's actions send a message encouraging payment.

A pattern of receiving payments also might constitute an act of implicit inducement. A pattern of receipt can send a clear message of expectation to prospective payors. ${ }^{104}$ This communicative effect is confirmed by observers of political corruption. ${ }^{105}$ Thus, if a public official accepted payments on three occasions, and the receipt of those payments was known to parties dealing with the public official, the jury would be allowed to determine that the offcial was inducing payments by a pattern of receipt. However, the inference of inducement from a pattern of receiving payments should be permissible and not mandatory. Circumstances might indicate that the pattern of receipt did not amount to a communicative act; a jury could then conclude that an official did not intend to send a message to prospective payors. A jury might also find

fundraising in cases involving explicit quid pro quo and coercive demands. See Dozier, 672 F.2d at 536-40; Cerilli, 603 F.2d at 419-21. Current Justice Department policy calls for prosecution only in cases where campaign contributions are extorted by coercion or by "a specific, identifiable quid pro quo." UNITED STates ATTORNEYs' MaNUaL, supra note 71, § 9131.180 (italics in original). Thus, prosecutorial discretion is currently being exercised so as to avoid the application of the Hobbs Act extortion proscription to legitimate political fundraising activities. For a similar analysis concerning prosecutorial discretion and the prosecution of political fundraising under bribery laws, see J. NooNAN, supra note 14, at 650-51.

${ }^{104}$ See O'Grady, 742 F.2d at 694 (Pierce, J., concurring); United States v. Campo, 605 F. Supp. 886, 889 (S.D.N.Y. 1985). Although three judges concurred in $O^{\prime} G r a d y$ in the pattern-of-receipt theory solely to create a majority on the issue, they gave no reasons for rejecting the theory. See 742 F.2d at 695 (Newman, J., concurring).

${ }^{105}$ See supra note 20; cf. W. REISMAN, supra note 19, at 38 ("[I]t becomes clear that persistent patterns of bribery are part of a larger process in which the bribe recipient, though appearing passive, is, over time, an active participant. If not the active stimulator of a specific bribe transaction, he is the creator or sustainer of an effective political structure that maintains needs and incentives for bribe payments."). 
that no inducement has occurred in situations where the benefits received were minimal or simply customary.

The proper standard of inducement should also provide that the public official need not have initiated the transaction or conceived the scheme of payment. ${ }^{108}$ To require that the transaction begin with the official would result in acquittals as long as "the idea for the gift . . . originated in the mind of the giver." ${ }^{107}$ It would create a significant evidentiary burden on the prosecution, closely akin to the burden imposed by the theory that extortion and bribery are mutually exclusive. ${ }^{108}$ In contrast, requiring inducement but not initiation by the public official brings the offense in line with the wording of the statute and the historical nature of the offense without unduly hindering effective prosecutions.

\section{Conclusion}

In order to convict a public official of extortion under color of official right under the Hobbs Act, the prosecution should have to prove that the official has committed an act inducing a payment not due him. The requirement of an act of inducement is justified by the language of the statute, by congressional intent as reflected in the choice of the common law definition for the wording of the extortion proscription, by the practice of interpreting criminal statutes to promote fair notice, and by the desirability of limiting prosecutorial discretion where there are both special incentives and ample opportunity for abuse.

The purposes of the Hobbs Act are best served by defining inducement as a communicative act by an official that is intended to encourage consensual transfer of property to the official. This definition allows inducement to be inferred from a pattern of receiving payments. Inducement should not, however, carry the requirement that the public official initiate the transaction.

James P. Fleissner

${ }^{108}$ This conflicts with the court's position in O'Grady, 742 F.2d at 691 (extortion must begin with the official, not with the gratuitous action of another).

${ }^{107}$ Id. at 696 (Van Graafeiland, J., concurring and dissenting).

${ }^{108}$ See supra notes 20-23 and accompanying text. 